\title{
A mutation at IVS1 +5 of the von Hippel-Lindau gene resulting in intron retention in transcripts is not pathogenic in a patient with a tongue cancer?: case report
}

Takeshi Asakawa ${ }^{1,2}$, Mariko Esumi ${ }^{2 *}$, Sohei Endo ${ }^{1}$, Akinori Kida ${ }^{1}$ and Minoru Ikeda ${ }^{1}$

\begin{abstract}
Background: Von Hippel-Lindau disease $(\mathrm{VHL})$ is a dominantly inherited familial cancer syndrome predisposing the patient to a variety of malignant and benign neoplasms, most frequently hemangioblastoma, renal cell carcinoma, pheochromocytoma, and pancreatic tumors. VHL is caused by mutations of the VHL tumor suppressor gene on the short arm of chromosome 3, and clinical manifestations develop if both alleles are inactivated according to the two-hit hypothesis. VHL mutations are more frequent in the coding region and occur occasionally in the splicing region of the gene. Previously, we reported that the loss of heterozygosity $(\mathrm{LOH})$ of the VHL gene is common in squamous cell carcinoma tissues of the tongue.
\end{abstract}

Case Presentation: We describe a case of squamous cell carcinoma in the tongue caused by a point mutation in the splicing region of the VHL gene and discuss its association with VHL disease. Sequence analysis of DNA extracted from the tumor and peripheral blood of the patient with squamous cell carcinoma revealed a heterozygous germline mutation (c. $340+5 \mathrm{G}>\mathrm{C}$ ) in the splice donor sequence in intron 1 of the VHL gene. RTPCR analysis of the exon1/intron1 junction in RNA from tumor tissue detected an unspliced transcript. Analysis of $\mathrm{LOH}$ using a marker with a heterozygous mutation of nucleotides ( $\mathrm{G}$ or $\mathrm{C}$ ) revealed a deletion of the mutant $\mathrm{C}$ allele in the carcinoma tissues.

Conclusions: The fifth nucleotide $\mathrm{G}$ of the splice donor site of the VHL gene is important for the efficiency of splicing at that site. The development of tongue cancer in this patient was not associated with VHL disease because the mutation occurred in only a single allele of the VHL gene and that allele was deleted in tumor cells.

\section{Background}

Von Hippel-Lindau (VHL) disease has a prevalence of about 1 per 36,000 people with $20 \%$ of cases being sporadic and $80 \%$ familial $[1,2]$. The causal gene, $V H L$, is located on chromosome $3 \mathrm{p} 26-25$ and is known to act as a tumor-suppressor gene [3]. It has three exons that code for 213 amino acids and has functions to promote ubiquitination of hypoxia inducible factor 1- alpha [4]. There are characteristic abnormalities of the $V H L$ gene in germline mutations from VHL disease and somatic mutations from sporadic cancers: more than a half of the

\footnotetext{
* Correspondence: esumi.mariko@nihon-u.ac.jp

${ }^{2}$ Department of Pathology, Nihon University School of Medicine, 30-1,

Ohyaguchikami-cho, Itabashi-ku, Tokyo 173-8610, Japan

Full list of author information is available at the end of the article
}

former are missense mutations whereas $70 \%$ of the latter are frameshift mutations $[5,6]$. Thus, most pathogenic mutations are located in the coding region of the $V H L$ gene. There are a few cases with splicing abnormality of the $V H L$ gene and it is not yet clear whether an abnormal transcript of the $V H L$ is pathogenic. In this report, we describe a splicing abnormality of the $V H L$ gene in a patient with a squamous cell carcinoma (SCC) of the tongue.

\section{Case Presentation}

The patient is a 55-year male with a tumor of the tongue, whose biopsy revealed a SCC. The cancerous tissue of the tongue along with peripheral blood were collected and stored at $-80^{\circ} \mathrm{C}$. Control material, both cancerous and non-

\section{Biomed Central}


cancerous, was obtained from a lingual cancer patient who did not have a $V H L$ mutation. DNA was extracted from the tissue lysate using the phenol/chloroform method. DNA was extracted from whole blood as described previously [7]. Total RNA was prepared from cancerous tissue using Trizol (Invitrogen, Carlsbad, CA) according to the manufacturer's instructions. The study was approved by the Ethical Committee of Nihon University School of Medicine, conforming to the Helsinki Declaration. The patient gave his written informed consent to participate in this study and for publication of this case report.
The three exons of the $V H L$ gene, and their flanking regions, were amplified as described previously [6]. The polymerase chain reaction (PCR) product was purified with a Microcon 100 filter (Amicon, Inc., Beverly, Mass.) and sequenced using a BigDye Terminator Cycle Sequencing kit (Applied Biosystems, Foster City, CA). We determined nucleotide sequences using an ABI310 Genetic Analyzer. We observed a heterozygous c. $340+5 \mathrm{G}>\mathrm{C}$ point mutation of the $V H L$ gene in the DNA from the cancerous tissue and peripheral blood of the patient with SCC of the tongue, but not in the control (Figure 1).

\section{VHL gene

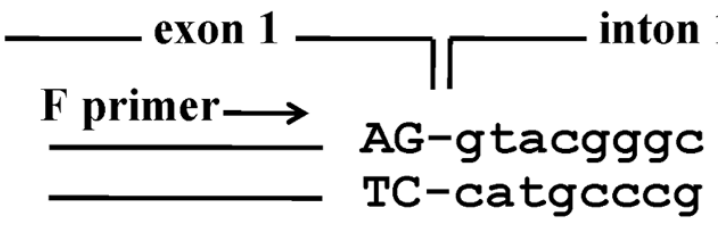

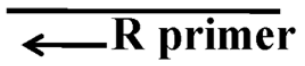

A

exon 1 intron 1

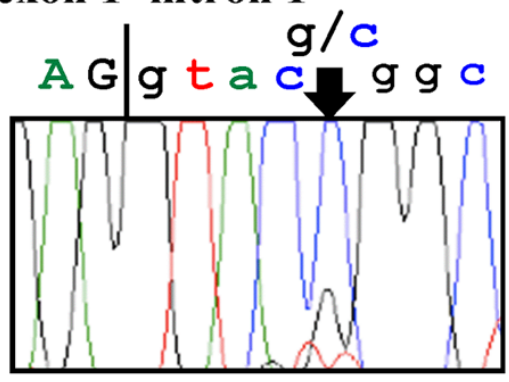

C

exon 1 intron 1

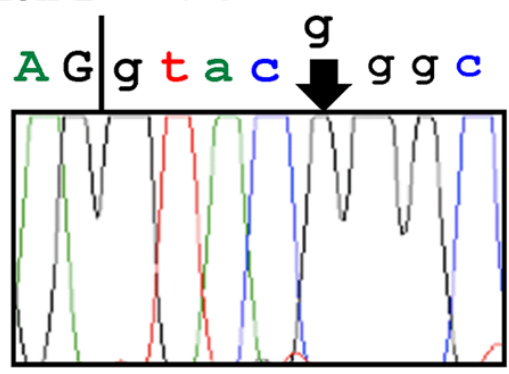

B

exon 1 intron 1

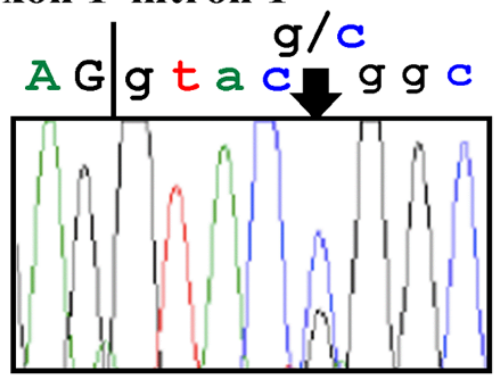

D

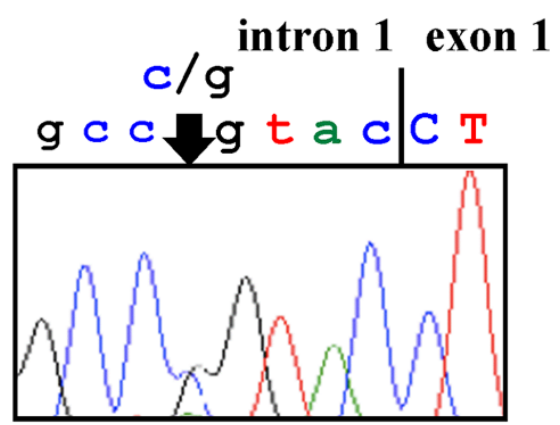

Figure 1 Sequence profiles of exon 1 to intron 1 of the $V H L$ gene. The sequence of exon 1 to intron 1 of the $V H L$ gene is shown in double- stranded form at the top. We compared DNA sequence from the cancerous tissue (A) and the peripheral blood (B) of the SCC patient to the non-cancerous tissue of a control patient (C). We observed a heterozygous C. $340+5 \mathrm{G}>\mathrm{C}$ point mutation of the VHL gene in the DNA from the cancerous tissue (A) and peripheral blood (B) of the patient with SCC of the tongue, but not in the control (C). The DNA from the peripheral blood of the patient was also sequenced in the reverse direction (D). 
The mutation is located at a splice donor site and could therefore lead to an unspliced transcription product.

To determine whether this had occurred, we amplified the transcription product using RT-PCR and performed real time PCR. Briefly, cDNA was synthesized from $2 \mu \mathrm{g}$ of DNase I-treated RNA from tumor tissue using 50 pmol of random primers and 5 units of AMV reverse transcriptase version 2.2 (Life Sciences, St. Petersburg, Florida, USA). To identify the exon 1-intron 1 and exon 1 -exon 2 regions, we performed SYBR Green PCR (Applied Biosystems) according to the manufacturer's instructions using intron primers E1/I1F (5'-CACAGCT ACCGAGGTACCG-3') and I1R (5'-GAATGCTCTGACGCTTACGA-3'), and exon primers 1/2 F (5'-AGCTACCGAGGTCACCTTTG-3') and 2/3R (5'-CAGAGT ATACACTGGCAGTG-3'), respectively. The amplifications were carried out by 40 cycles at $95^{\circ} \mathrm{C}$ for $15 \mathrm{sec}$ and $60^{\circ} \mathrm{C}$ for $60 \mathrm{sec}$ using an ABI7000 (Applied Biosystems). As a control, we used glyceraldehyde 3-phosphate dehydrogenase $(G A P D H)$ gene primers (5'-GGTCGG AGTCAACGGATTTG-3' and 5'-GCATCTCG CTCC TGGAAGAT-3'). PCR products were run on $2 \%$ agarose gels to confirm fragment sizes.

As shown in Figure $2 \mathrm{C}$, in our patient, a product of 167 bp was obtained by RT-PCR of tumor RNA with the exon 1 /intron 1 primer pair (E1/I1F and I1R), indicating that splicing of intron 1 had not occurred, at least in a portion of $V H L$ transcripts. We confirmed that the transcript contained the intron sequence by direct sequencing (data not shown). Analysis of cDNA from the control patient did not produce a similar length transcription product. We ensured that the result from our intron RT-PCR was not a signal from contaminating DNA by treating the total RNA samples with DNase I prior to cDNA production (Figure 2). Semi-quantitative analysis suggested that the relative amount of transcripts in tumor tissue exhibiting abnormal splicing of intron 1 was only $1.5 \%$ of that exhibiting normal splicing of exon 2 and 3.

Then, loss of heterozygosity $(\mathrm{LOH})$ of the $V H L$ gene was determined by SNaPshot quantification as described previously [8]. Briefly, PCR was performed using two pairs of primers at the heterozygous point mutation $\mathrm{G} / \mathrm{C}$ of the intron 1 splice donor site: E1/I1F (5'-CACAGCTACCG AGGTACCG-3') and I1R (5'-GAATGCTCTGACGCTTACGA-3') and at the SNP A/G of the exon 3: AGF (5'CTGCCCATTAGAGAAGTATTT-3') and AGR (5'-AAT TCCCACTGAATTACGTATA-3'). After purification using a Microcon 100 filter, the amplified product was subjected to a primer extension reaction using $\mathrm{SNaPshot}$

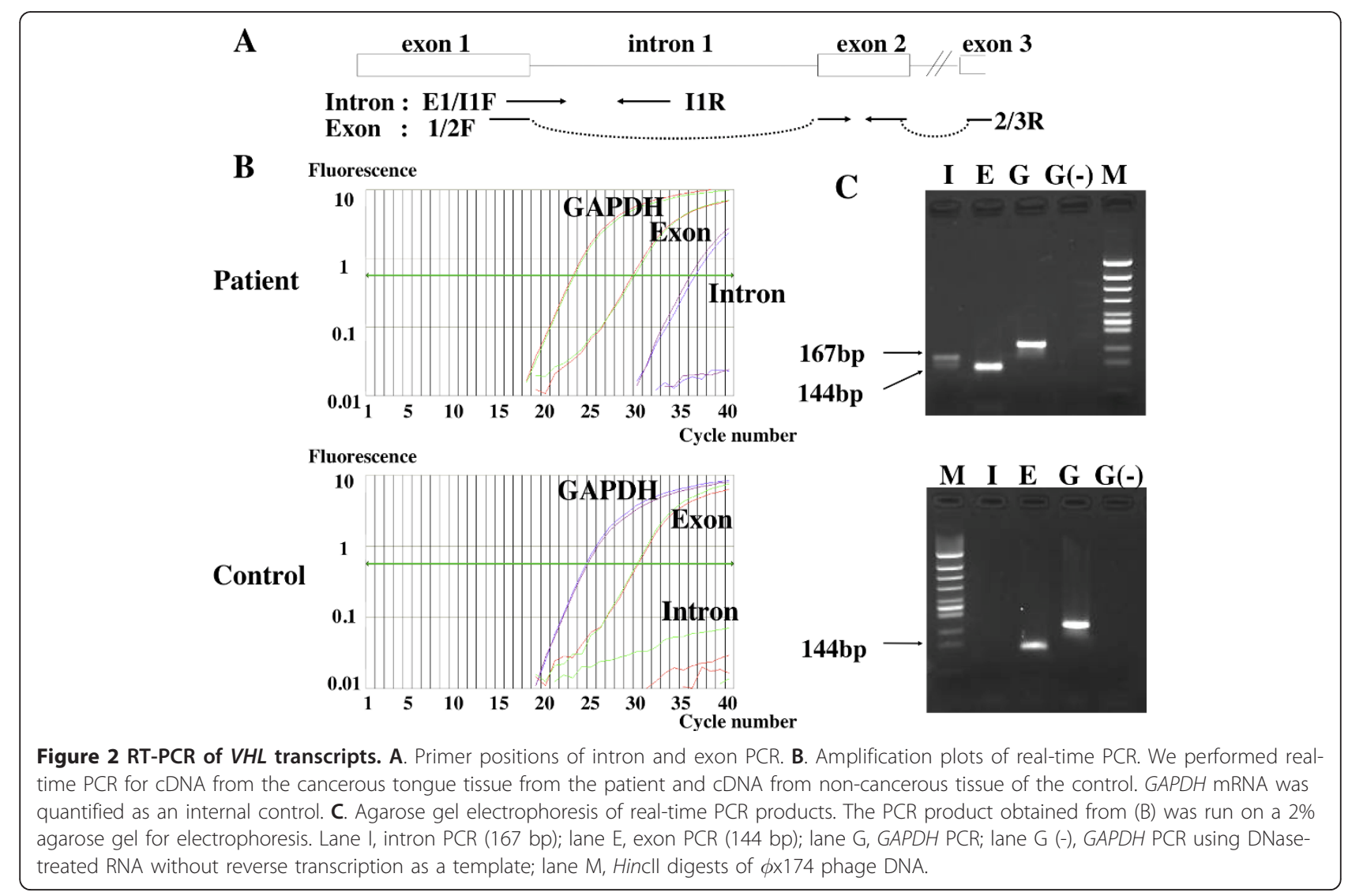


premix (Applied Biosystems) with the $\mathrm{SNaPshot} \mathrm{primers}$ 5'-GCCGCATCCACAGCTACCGAGGTAC-3' and 5'AGTCAGGACAGCTTGTATGTAAGGAGGTTT-3', respectively. The primer extension product was quantified using an ABI 310 genetic analyzer and GeneScan software (Applied Biosystems). The LOH analysis at the heterozygous point mutation (c.340 G > C) in intron 1 revealed that the tumor tissue had levels of the mutant allele that were about $50 \%$ lower than that observed in peripheral blood, suggesting loss of the mutant allele in tumor tissue (Figure 3). Thus, the reduction in intron transcription product was due to the loss of the mutant allele in the cancerous tissue.

As shown on Figure 1, we have found a germline point mutation, c. $340+5 \mathrm{G}>\mathrm{C}$, in the intron 1 splice donor site of the $V H L$ gene of a patient with SCC of the tongue. We demonstrated that this base substitution was a mutation that produces a transcription product with abnormal splicing. This is the first report of abnormal splicing due to a mutation at the +5 position in intron 1 of the $V H L$ gene. If the novel transcription product is translated without being spliced, then 35 amino acids and a stop codon would be read from intron 1 . The $\mathrm{C}$-terminally truncated polypeptide would compromise the elongin binding.

The consensus sequence of exon-intron junctions is $5^{\prime}-\mathrm{A}_{64} \mathrm{G}_{73} / \mathrm{G}_{100} \mathrm{~T}_{100} \mathrm{~A}_{62} \mathrm{~A}_{68} \mathrm{G}_{84} \mathrm{~T}_{63}-3^{\prime}$ in which the subscripts indicate the percent occurrence of the specified base. U1 snRNA (3'-UCCAUUCAUApppGm-5') base pairs directly with the 5 ' splice site at the first stage of splicing. The extent of complementarity between U1 snRNA and the 5' splice site is 4-6 bp. The exon 1intron 1 junction of the $V H L$ gene is 5'-AG/GTACGG3 ' in which the +4 and +6 positions of intron 1 are unpaired with U1 snRNA. Therefore, +5 position must be important to start splicing by base pairing with U1 snRNA.

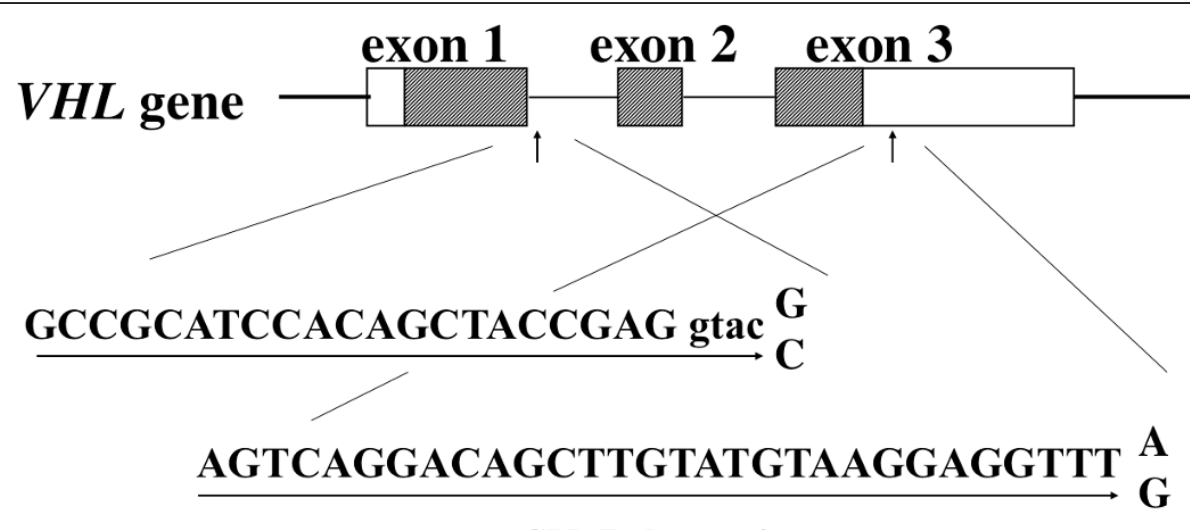

SNaPshot primer

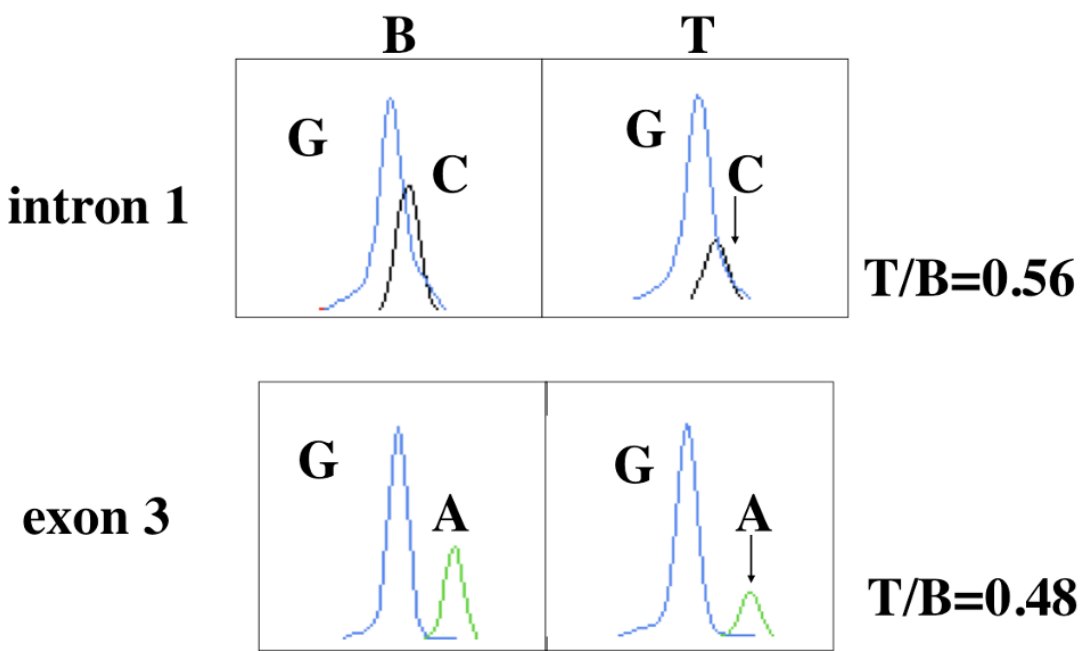

Figure $3 \mathbf{L O H}$ of the $V H L$ gene. LOH was analyzed at the heterozygous point mutation G/C of the intron 1 splice donor site and at the SNP A/ $\mathrm{G}$ of the exon 3 of the VHL gene using a quantitative genotyping method. Comparison of cancerous tissue (T) and the peripheral blood (B) of the SCC patient indicated that the cancerous tissue had lost the mutant C allele (arrow) and the SNP A allele (arrow). 
A germline mutation at intron 1 splice site of the $V H L$ gene has been found in numerous patients with VHL disease. Point mutations at IVS1 +1 [9,10] or IVS1-1 [10], and an insertion or deletion at the IVS1 splice site $[10,11]$ were found in several cases of VHL disease. The point mutation found here at IVS1 + 5 (G to $\mathrm{C}$ conversion) was present in cases of VHL disease type 1 [11-14]. Therefore, a point mutation at IVS1 +5 can result in the abnormal splicing and are pathogenic. However, although there is abnormal splicing in the present case, the patient did not fulfill the current clinical diagnostic criteria of VHL disease [15] and had no family history of VHL disease. There are two possible interpretations for this apparent paradox. First, the patient has not yet developed VHL disease. Second, the mutation may not always be pathogenic and the patient will not develop VHL disease. Erlic et al. questioned the pathogenicity of the c. $340+5 \mathrm{G}>\mathrm{C}$ mutation since it did not segregate with VHL in his family [16]. The question arises of whether the tongue cancer of the present patient is a VHL disease-associated cancer? The answer appears to be that it is not as there was no second hit from somatic cell mutation of the wild type $V H L$ allele, although there was loss of the mutant allele in the tumor tissue. It is possible that the single hit allelic loss of the $V H L$ gene increased the risk of cancer development. Recently, we observed frequent $\mathrm{LOH}$ of the $V H L$ gene in sporadic tongue cancer but no somatic cell mutations such as missense, nonsense, and frameshift mutations [17]. $\mathrm{LOH}$ of several microsatellites on $3 \mathrm{p}$ was also detected in significant proportion of tongue cancer patients, and such deletions were often observed simultaneously across a large region of $3 p$ within the same tumor sample [17]. The present patient showed LOH at all 5 informative microsatellites examined on $3 p$ in addition to the $V H L$ gene [17]. Thus, multiple tumor-suppressor genes on $3 p$ may play a role in the development of tongue cancer in the present case.

\section{Conclusions}

The fifth nucleotide $\mathrm{G}$ of the splice donor site of the $V H L$ gene is important for the efficiency of splicing at that site. The development of tongue cancer in this patient was not associated with VHL disease because the mutation occurred in only a single allele of the $V H L$ gene.

\footnotetext{
Abbreviations

IVS: intervening sequence; VHL: von Hippel-Lindau; SCC: squamous cell carcinoma; PCR: polymerase chain reaction; GAPDH: glyceraldehyde 3phosphate dehydrogenase; RT-PCR: reverse transcription-polymerase chain reaction; LOH: Loss of heterozygosity.
}

\section{Acknowledgements}

We are indebted to NAI for this editorial assistance, and Nihon University School of Medicine who provided an educational grant to support the study and the manuscript preparation.

\section{Author details}

${ }^{1}$ Department of Otorhinolaryngology-Head and Neck Surgery, Nihon University School of Medicine, Tokyo173-8610, Japan. ${ }^{2}$ Department of Pathology, Nihon University School of Medicine, 30-1, Ohyaguchikami-cho, Itabashi-ku, Tokyo 173-8610, Japan.

\section{Authors' contributions}

SE and AK diagnosed the patient, collected the clinical data, and participated in the editing of the manuscript. MI participated in the editing of the manuscript. TA carried out the molecular genetic studies and drafted the manuscript. ME conceived of the study, participated in its design and helped to draft the manuscript. All authors have read and approved the final manuscript.

\section{Competing interests}

The authors declare that they have no competing interests.

Received: 12 September 2011 Accepted: 31 March 2012 Published: 31 March 2012

\section{References}

1. Maher ER, Iselius L, Yates JR, Littler M, Benjamin C, Harris R, Sampson J, Williams A, Ferguson-Smith MA, Morton N: Von Hippel-Lindau disease: a genetic study. J Med Genet 1991, 28:443-447.

2. Yoshida M, Ashida S, Kondo K, Kobayashi K, Kanno H, Shinohara N, Shitara N, Kishida T, Kawakami S, Baba M, Yamamoto I, Hosaka M, Shuin T, Yao M: Germ-line mutation analysis in patients with von Hippel-Lindau disease in Japan: an extended study of 77 families. Jpn J Cancer Res 2000, 91:204-212.

3. Latif F, Tory K, Gnarra J, Yao M, Duh FM, Orcutt ML, Stackhouse T, Kuzmin I, Modi W, Geil L, Schmidt L, Zhou F, Li H, Wei H, Chen F, Glenn G, Choyke P, Walther MM, Weng Y, Duan DR, Dean M, Glavac D, Richards FM, Crosay PA, Ferguson-Smith MA, Paslier DL, Chumakov I, Cohen D, Chinault AC, Maher ER, Linehan WM, Zbar B, Lerman MI: Identification of the von Hippel-Lindau disease tumor suppressor gene. Science 1993, 260:1317-1320.

4. Cockman ME, Masson N, Mole DR, Jaakkola P, Chang GW, Clifford SC, Maher ER, Pugh CW, Ratcliffe PJ, Maxwell PH: Hypoxia inducible factoralpha binding and ubiquitylation by the von Hippel-Lindau tumor suppressor protein. J Biol Chem 2000, 275:25733-25741.

5. Gallou C, Joly D, Mejean A, Staroz F, Martin N, Tarlet G, Orfanelli MT, Bouvier R, Droz D, Chretien Y, Marechal JM, Richard S, Junien C, Beroud C: Mutations of the $\mathrm{VHL}$ gene in sporadic renal cell carcinoma: definition of a risk factor for VHL patients to develop an RCC. Hum Mutat 1999, 13:464-475.

6. Hamano K, Esumi M, Igarashi H, Chino K, Mochida J, Okada K: Biallelic inactivation of the von Hippel-Lindau tumor suppressor gene in sporadic renal cell carcinoma. J Urol 2002, 167:713-717.

7. John SW, Weitzner G, Rozen R, Scriver CR: A rapid procedure for extracting genomic DNA from leukocytes. Nucleic Acids Res 1991, 19:408.

8. Mochida J, Esumi M, Kitajima A, Okada K: Allelic loss analysis of tumor suppressor genes regardless of heterozygosity: von Hippel-Lindau gene loss in renal cell carcinoma. J Urol 2008, 180:724-728.

9. Glasker S, Bender BU, Apel TW, Natt E, van Velthoven V, Scheremet R, Zentner J, Neumann HP: The impact of molecular genetic analysis of the VHL gene in patients with haemangioblastomas of the central nervous system. J Neurol Neurosurg Psychiatry 1999, 67:758-762.

10. Olschwang S, Richard S, Boisson C, Giraud S, Laurent-Puig P, Resche F, Thomas G: Germline mutation profile of the VHL gene in von HippelLindau disease and in sporadic hemangioblastoma. Hum Mutat 1998, 12:424-430.

11. Stolle C, Glenn G, Zbar B, Humphrey JS, Choyke P, Walther M, Pack S, Hurley K, Andrey C, Klausner R, Linehan WM: Improved detection of germline mutations in the von Hippel-Lindau disease tumor suppressor gene. Hum Mutat 1998, 12:417-423.

12. Zbar B, Kishida T, Chen F, Schmidt L, Maher ER, Richards FM, Crossey PA, Webster AR, Affara NA, Ferguson-Smith MA, Brauch $H$, Glavac D, Neumann HP, Tisherman S, Mulvihill JJ, Gross DJ, Shuin T, Whaley J, Seizinger B, Kley N, Olschwang S, Boisson C, Richard S, Lips CHM, Linehan WM, Lerman M: Germline mutations in the Von Hippel-Lindau 
disease (VHL) gene in families from North America, Europe, and Japan. Hum Mutat 1996, 8:348-357.

13. Maher ER, Webster AR, Richards FM, Green JS, Crossey PA, Payne SJ, Moore AT: Phenotypic expression in von Hippel-Lindau disease: correlations with germline VHL gene mutations. J Med Genet 1996, 33:328-332.

14. Zhou J, Wang J, Li N, Zhang X, Zhou H, Zhang R, Ma H, Zhou X: Molecularly genetic analysis of von Hippel-Lindau associated central nervous system hemangioblastoma. Pathol Int 2010, 60:452-458.

15. Lonser RR, Glenn GM, Walther M, Chew EY, Libutti SK, Linehan WM, Oldfield EH: von Hippel-Lindau disease. Lancet 2003, 361:2059-2067.

16. Erlic Z, Hoffmann MM, Sullivan M, Franke G, Peczkowska M, Harsch I, Schott M, Gabbert HE, Valimaki M, Preuss SF, Hasse-Lazar K, Waligorski D, Robledo M, Januszewicz A, Eng C, Neumann HP: Pathogenicity of DNA variants and double mutations in multiple endocrine neoplasia type 2 and von Hippel-Lindau syndrome. J Clin Endocrinol Metab 2010, 95:308-313.

17. Asakawa T, Esumi M, Endo S, Kida A, lkeda M: Tongue cancer patients have a high frequency of allelic loss at the von Hippel-Lindau gene and other loci on 3p. Cancer 2008, 112:527-534.

\section{Pre-publication history}

The pre-publication history for this paper can be accessed here: http://www.biomedcentral.com/1471-2350/13/23/prepub

doi:10.1186/1471-2350-13-23

Cite this article as: Asakawa et al: A mutation at IVS1 +5 of the von Hippel-Lindau gene resulting in intron retention in transcripts is not pathogenic in a patient with a tongue cancer?: case report. BMC Medical Genetics 2012 13:23.

\section{Submit your next manuscript to BioMed Central and take full advantage of:}

- Convenient online submission

- Thorough peer review

- No space constraints or color figure charges

- Immediate publication on acceptance

- Inclusion in PubMed, CAS, Scopus and Google Scholar

- Research which is freely available for redistribution

Submit your manuscript at www.biomedcentral.com/submit 